\title{
Article
}

\section{Determinants of willingness to pay for non-technical irrigation in East Java, Indonesia}

\author{
Rondhi Muhammad 1,*, Peratama Bagus ${ }^{1}$, Budiman Subhan ${ }^{2}$, and Suwandari Anik ${ }^{3}$ and Ridjal \\ Julian $^{3}$ \\ 1 Dept.of Agricultural Economic, Jember University; rondhi.faperta@unej.ac.id; peratama280713@yahoo.com \\ 2 Dept. of Soil Science, Jember University; sabudiman@gmail.com \\ 3 Dept. of Agribusiness, Jember University; anik.faperta@unej.ac.id; adam.faperta@unej.ac.id \\ * Correspondence: rondhi.faperta@unej.ac.id; Tel.. +6281291495040
}

\begin{abstract}
Declining water supply is the main cause of rising water fee for agricultural use. Moreover, in non-technical irrigation, poor irrigation infrastructure exacerbates water scarcity. Thus, the purpose of this study is to identify farmer willingness to pay for non-technical irrigation and its determinants. Structured questionnaire was used to collect data from 100 farmers. Contingent valuation method was employed to elicit farmer WTP and multiple linear regression was used to find its determinants. The result shows that farmer average WTP is Rp 3,055,168 /ha/year. It accounts for 20 percent of total farmer revenue and almost 20 times fee for technical irrigation. Economic and technical variables are the significant determinants of WTP while social variables seem insignificant to WTP. This result indicates high economic value of water, and to improve irrigation management we recommend establishing irrigation infrastructure gradually by mobilizing farmer resources (capital and management) and strengthening WUA.
\end{abstract}

Keywords: Contingent valuation method, economic value of water, farmer-managed irrigation system

\section{Introduction}

Agricultural sector is the largest consumer of water in the world which spends nearly 70 percent of available water [1,2]. The major challenge concerning water faced by agricultural sector today is the rising scarcity of water and difficulty to find, or even the nonexistent of, new supplies of water [3]. Furthermore, in area with non-technical irrigation, poor canal conditions exacerbate water loss making irrigation less efficient. ${ }^{1}$ Hence, the main focus of agricultural water management policy is to promote efficiency, equity, and sustainability of water allocation [4].

There are two major policies implemented to achieve those goals; technical intervention and management intervention [5]. The former characterized by massive irrigation infrastructure establishment and aimed to serve wide area, while the latter usually aimed at improving the capacity of farmer organization to manage irrigation at farm level. However, both of these policies only targeting technically irrigated area leaving area irrigated by non-technical irrigation untouched. While on the other hand, non-technical irrigation, especially those in the mountain region, had been established and well managed by farmer. ${ }^{2}$ However, increasing water scarcity makes it difficult to provide water in a timely manner, reduces irrigation efficiency, and threaten its sustainability. Although farmer can cope with water scarcity by introducing high cost technology such as water pump, it is evident that improved irrigation infrastructure will increase irrigation efficiency and reduces its costs.

\footnotetext{
1 non-technical irrigation defined as irrigation system in which: water distribution is not measured, water tend to flow to drainage canal, irrigation system managed by farmer (low government involvement), water available in abundance. The main drawbacks are poor irrigation infrastructure and severe water loss [19].

2 for a review of farmer managed irrigation system, see [20,21]
} 
Improving irrigation infrastructure at farm level requires a large amount of capital. Moreover, the turnover program implemented in 1980s reduces government fund allocated for its establishment. Thus, it is important to find alternative sources of fund especially those coming from farmer. Utilizing farmer own resources to improve non-technical irrigation infrastructure has two important merits. First, farmer in those area has been accustomed to manage irrigation independently, thus it is more likely that they are willing to provide their own fund to establish irrigation infrastructure. Second, using their own fund will increase their sense of ownership and increase participation in and sustainability of irrigation. However, mobilizing farmer resources is not an easy task when farmer perceive the benefits they will receive is not greater than the cost they should provide. Hence, it is important to assess first the economic value of irrigation water by which we can derive the benefit and cost accrued to farmer associated with irrigation.

The economic value of irrigation can be determined by measuring farmer willingness to pay (WTP) for it. The economic benefit received by farmer from irrigation, which is typically higher, revealed through WTP. Another important characteristic of WTP is that it can be used as an instrument to allocate water under reduced water supplies and water rights [6]. Thus, the main purpose of this study is to measure farmer WTP for non-technical irrigation and identify its determinants. The rest of the paper is structured as follows, in the next section we present the methods employed in this study; in section 3, we present the result and discuss important findings; in the last section, we conclude our study and mention policy implications regarding the findings of this study.

\section{Materials and Methods}

\subsection{Study Area}

This study was conducted at Curahtakir village. It is located in the eastern region of East Java, at the sub-district of Tempurejo on the district of Jember. Like typical Indonesian village, Curahtakir is dominated by agriculture. However, since geographically it is located in the mountain region (Raung Volcano), technical irrigation does not exist there. Agricultural irrigation provided and managed by farmer utilizing water coming from spring. ${ }^{3}$

We study one irrigation system serving an area of 144 hectares managed by 276 farmers. The main reason for selecting Curahtakir is its distinct irrigation characteristic. Curahtakir's irrigation categorized as non-technical/simple irrigation. In Indonesia, approximately 40.5 percent of agricultural land is irrigated by non-technical irrigation [7]. Accounting for such a big proportion, it plays an important role in Indonesian national plan to achieve food (rice, maize, and soybean) selfsufficiency in production.

Based on land altitude the studied irrigation system divided into three sections: upper, middle and lower area. There are three cropping seasons annually in these area with relatively similar cropping pattern in each section, which is paddy in the first and second season, and mostly maize in the last season. ${ }^{4}$ The distinguishing characteristic among them are water availability and water provider which vary among cropping season.

On the first season water is sufficient in all area since most of water coming from rainfall. While on the second season, spring water as the main supplies of irrigation water can only provide water for upper and some part of the land in the middle and lower area. Moreover, on the third season irrigation water available only in the upper area and water in the middle and lower area provided by water pump. Irrigation from spring in provided by Water User Association (WUA) and operated by WUA official called ulu-ulu. ${ }^{5}$ However, when water is not sufficient in the second and third season at lower and middle area, irrigation is provided by private water pump.

\footnotetext{
${ }^{3}$ Irrigation in the study area can be defined as gravity-flow hill irrigation, for detailed discussion on the technical and management aspects of this irrigation see $[22,23]$

${ }^{4}$ Actually, the cropping season divided based on two main seasons in Indonesia, rainy and dry season. The first cropping season called rainy season, while the second and the third season called dry season 1 and dry season 2 respectively.

${ }^{5}$ There are three $u l u$-ulu in the study area, one person for each section.
} 

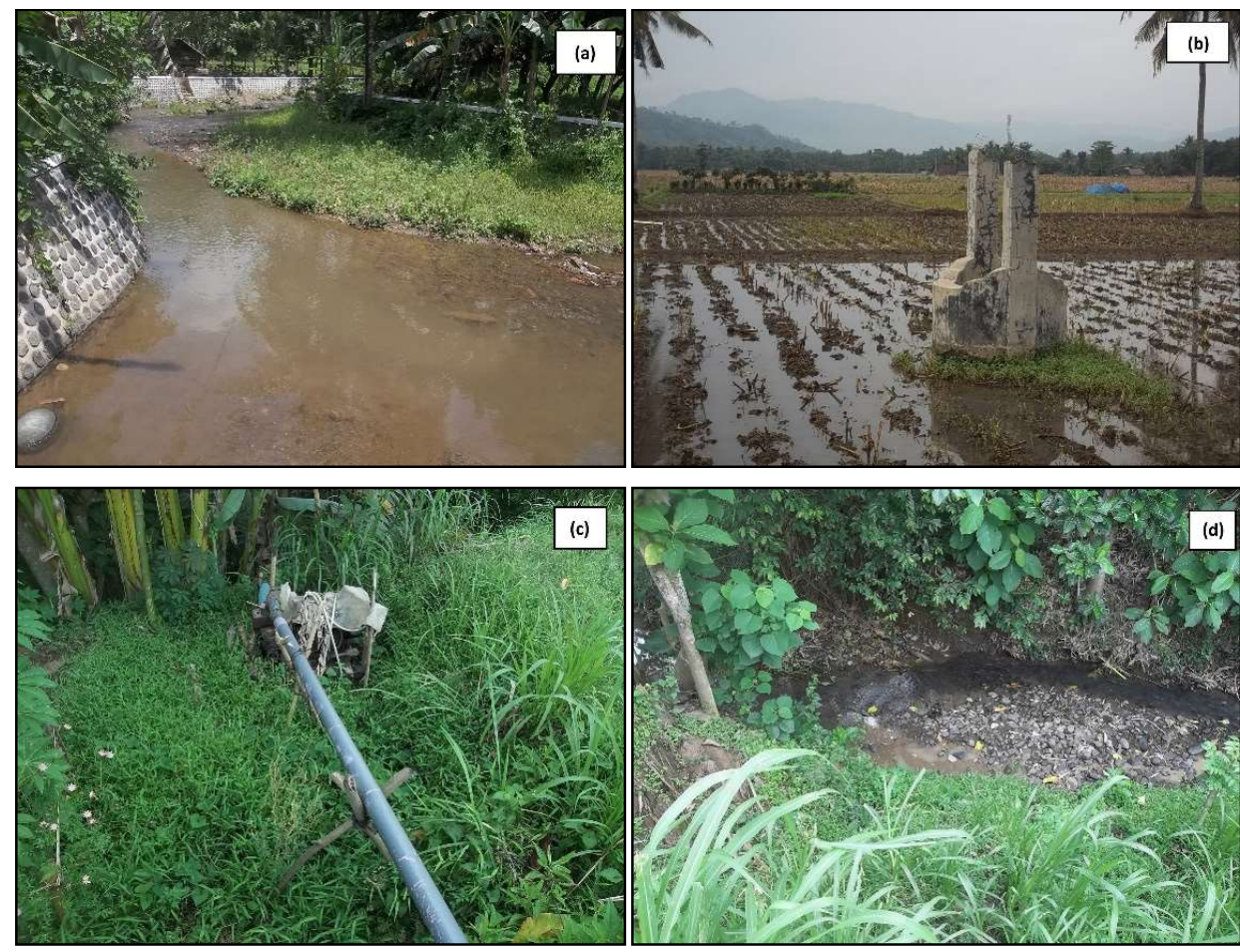

Figure 1. Irrigation system in the studied area. (a) Agung dam, the main water reservoir; (b) Farmer digging well; (c) Private water pump ; (d) Irrigation and drainage canal. 


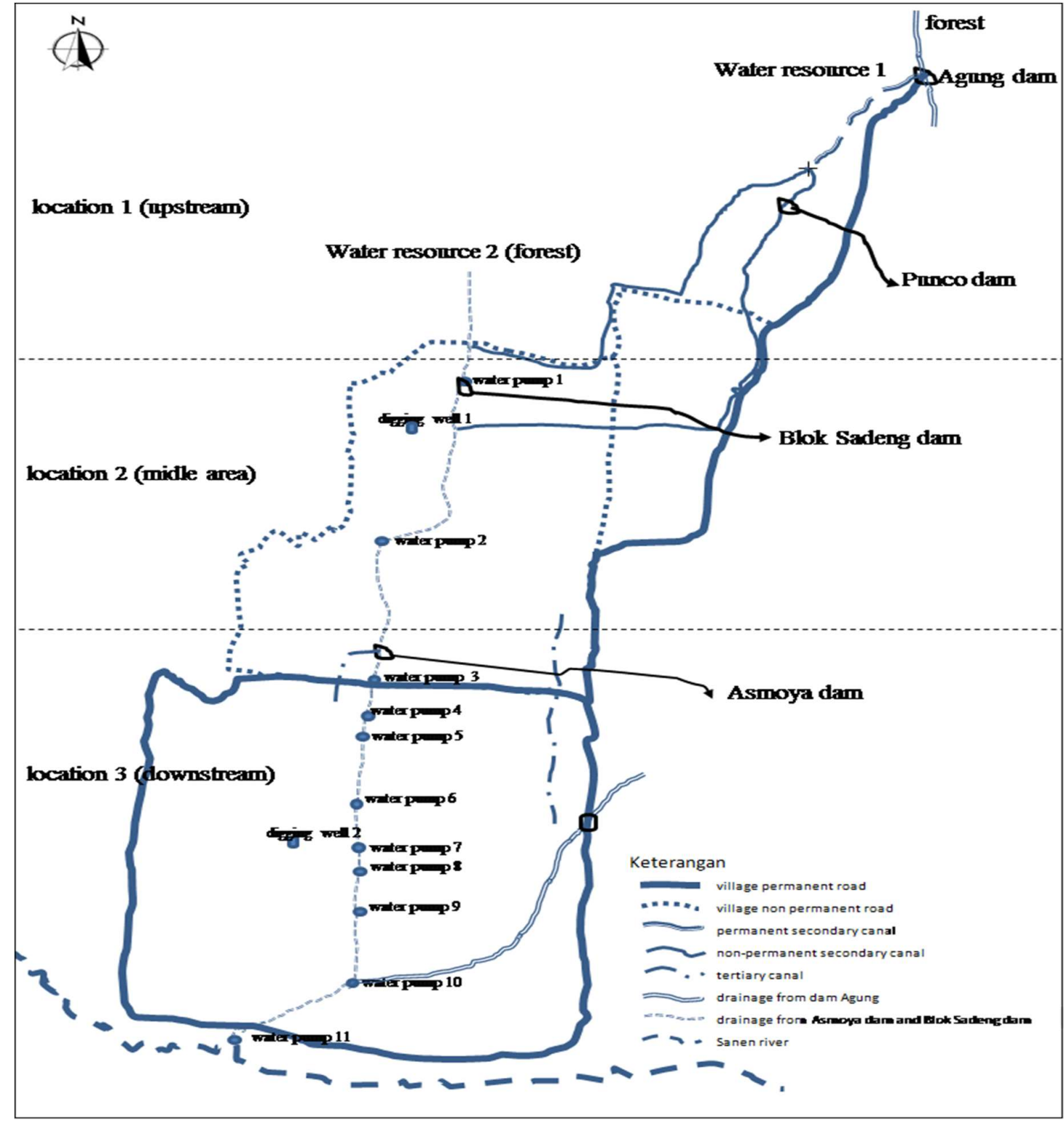

Figure 2. The scheme of studied irrigation system

As shown in figure 1, water coming from spring in the forest stored in 4 dams: agung and punco dams in the upper area, bloksadeng and asmoya dam in the middle and lower area respectively. ${ }^{6}$ There are two other sources of water in the middle and lower area which are two digging wells and eleven water pumps. Both middle and lower area have one digging well but there are only three water pumps located in the middle area while the rest of them located in the lower area. The large number of water pump required in the lower area since the water scarcity is high in those area on the second and third season.

${ }^{6}$ Water scarcity in this area not only affected by rain intensity but also by rate of deforestation. According to farmer, deforestation has reduced significantly the quantity of spring water than it was three decades ago. 


\subsection{Data}

Research sample was determined using simple random sampling. On the initial sampling stage, farmer population was determined with the help of $u l u-u l u .{ }^{7} \mathrm{~A}$ sample of 100 farmers was interviewed from a total of 276 farmers. ${ }^{8}$ The sampling number was determined using following formula.

$$
n=\frac{N}{1+N(e)^{2}}
$$

Where $n$ is the sample size, $N$ is the population size and $e$ are the error tolerance of the sample. With a sample size of 100 farmers the error tolerance is 7.9 percent. It means there is a 7.9 percent range of tolerated error in the data. In the case of farmer willingness to pay, the sample WTP may be 7.9 percent higher or lower than the population WTP.

Structured questionnaire was used to gather data by interviewing sample farmer from Curahtakir village. The main characteristic of Curahtakir agriculture is that it irrigated using water coming from spring utilizing non-technical irrigation infrastructure. However, in dry season spring water can only serve upper area making middle and lower area has to use water pump for irrigation. Thus, the sample farmer used in this study dispersed in all these three areas.

The questionnaire was consisted of 3 sections. The first section focuses on social and economic characteristics of farmer. This section divided into 4 parts. The first part dealt with farmer identity, in this part farmer age (X2), education (X3), and income (X4) were identified. The rest of the first section structured as follows: the second part dealt with general farming conditions, the third part dealt with cultivation land status and size (X1), and the last part dealt with annual cropping calendar.

The second section focuses on irrigation management in each cropping season. This section divided into 3 parts, each dealt with irrigation management in rainy season, first dry season, and second dry season. The focus on each part is on technical aspect of irrigation such as: the source of water, distance of farmer plot to water source (X5), who provide irrigation service and service fee, irrigation schedule, and irrigation management in dry season (D). Irrigation management in dry season is dummy variable to categorize farmer who use water pump and those who not, to irrigate their land in dry season.

The last section of the questionnaire focuses on eliciting farmer WTP for irrigation. This section consisted of 12 questions which aimed to explore how farmer perceive the current irrigation price and what is the highest price they are able to afford. In this section farmer was also asked about what they will do when irrigation price is beyond their ability to pay. Lastly, this section also consists of the role of $u l u-u l u$ as current irrigation provider.

\subsection{Analytical procedures}

\subsubsection{Contingent valuation method}

The first step of analysis is determining the farmers WTP. In determining WTP we use contingency value method (CVM). Actually, there are two ways in measuring WTP, revealed preference and stated preference methods. Revealed preference utilizing the actual payment data to measure WTP, while the stated preference method measure WTP by direct survey and utilized when there is no adequate information about historical payment data [8]. CVM is the most commonly used method to measure WTP for non-marketed goods and it has two main advantages: (1) its ability to evaluate proposed goods or services; (2) its usefulness in addressing value that cannot be dealt with any other way $[9,10]$.

TResponsible for irrigation operation, $u l u$-ulu knows exactly how many farmers under his responsibilities and where their plot located.

${ }^{8}$ The link to questionnaire and full dataset used for this study can be obtained at Supplementary section. 
Table 1. variables in the model

\begin{tabular}{clcl}
\hline No & \multicolumn{1}{c}{ Variable } & Code & \multicolumn{1}{c}{ Description } \\
\hline 1. & Farm size & X1 & The size of farmer land (in hectare) \\
2. & Age & X2 & The farmer age (in years) \\
3. & Education & X3 & Farmer formal education (in years of schooling) \\
4. & Income & X4 & Farmer income in one cropping season (Rp/hectare) \\
5. & Distance to small dam & $\mathrm{X} 5$ & Distance of farmer land to small dam (m) \\
6. & Management in dry & $\mathrm{D}$ & Dummy variable representing type of irrigation used \\
& season & & $\begin{array}{l}\text { in dry season, (1) private water pump; (0) Irrigation } \\
\text { from WUA }\end{array}$ \\
\hline
\end{tabular}

Multiple linear regression estimates the nominal value of farmer WTP from the identified social, economic, and technical characteristics. Our predicted variable is the WTP value obtained from contingent valuation method while X1 through X5 and Dare the explanatory variables. The multiple linear regression was based on least square estimation and estimation performed with SPSS ver. 17. The empirical model can be written as follows.

$$
W T P=b+b_{1} x_{1}+b_{2} x_{2}+b_{3} x_{3}+b_{4} x_{4}+b_{5} x_{5}+b_{6} D
$$

Since our empirical model contains a dummy variable representing two group ( 1 for those who use water pump in dry season; 0 for those who not), the final model consists of two equations as follow.

$$
\begin{aligned}
& \mathrm{WTP}_{1}=b+b_{6}+b_{1} x_{1}+b_{2} x_{2}+b_{3} x_{3}+b_{4} x_{4}+b_{5} x_{5} \\
& W P_{0}=b+b_{1} x_{1}+b_{2} x_{2}+b_{3} x_{3}+b_{4} x_{4}+b_{5} x_{5}
\end{aligned}
$$

Where $W T P_{1}$ is the WTP of farmer who apply water pump to irrigate their crop during dry season while $W T P_{0}$ is the WTP of farmer who doesn't apply water pump in dry season. $b$ is the regression intercept and the other $b(s)$ are the regression coefficients of the variables.

\section{Results}

\subsection{Willingness to pay}

Willingness to pay for irrigation vary in location and season, mostly attributed to water scarcity and difficulties in providing water to farmer plot. Figure 2. shows WTP for each season in each location. As water scarcity increase during second and third season, the WTP increase respectively. In the first season when water is sufficiently available, the average WTP is lowest. The average WTP for upper, middle, and lower location are 227,766; 388,462; and 333.746 respectively. ${ }^{9}$ While the average WTP for the second season are 439,243; 2,246,154; and 1,530,992 for upper, middle, and lower area. This is significantly higher than irrigation water fee charged in area with technical irrigation, as [11], identified water fee paid by farmer in Bogor and Kudus are 75.000 and 150.000 per hectare annually. ${ }^{10}$

These results demonstrate that water plays role as an economic good in condition of rising water scarcity. Although our current study focused on irrigation from spring water, this condition however, has been identified for almost all kind of water such as, ground water [12] surface water [13], and even for the demand of recycled water for irrigation [14]. Moreover, the cost for irrigation farmer should pay is account for 20 percent of their revenue. ${ }^{11}$ However, the identified WTP is the

\footnotetext{
9 WTP is in Rp/ha/season, current exchange rate for Indonesian Rupiah is US\$ 1 = IDR 14.085 (Bloomberg.com, May 9 2018)

${ }^{10}$ Bogor and Kudus are two districts located in Province of West and Central Java.

${ }^{11}$ Total WTP for sample farmer is Rp 83,480,000.00 and total revenue is Rp 448,600,000.00
} 
highest value the farmer is willing to pay, when asked what they will do when water price go higher than the current level, they prefer to plant another crop which require less water. ${ }^{12}$

In total the average irrigation cost paid for the entire plot (144 hectares) is Rp 439,944,128.82. Furthermore, there is significance WTP increase of 578 and 458 percent in the middle and lower area while WTP in upper area has an increase of only 192 percent. This number further increase in the third season with 260, 799, and 684 percent increase for upper and, middle, and lower area. This figure indicates that the economic value of water for farmer is high and thus it is likely that they are willing to invest in an effort to build irrigation infrastructure which lessen the irrigation cost and increase its efficiency.

Although water scarcity is increasing with lowering land altitude, the fact that the middle area has the highest WTP in all seasons shows that the value of water not only affected by the availability of water. Hence, it is important to further investigate the determinants of WTP.

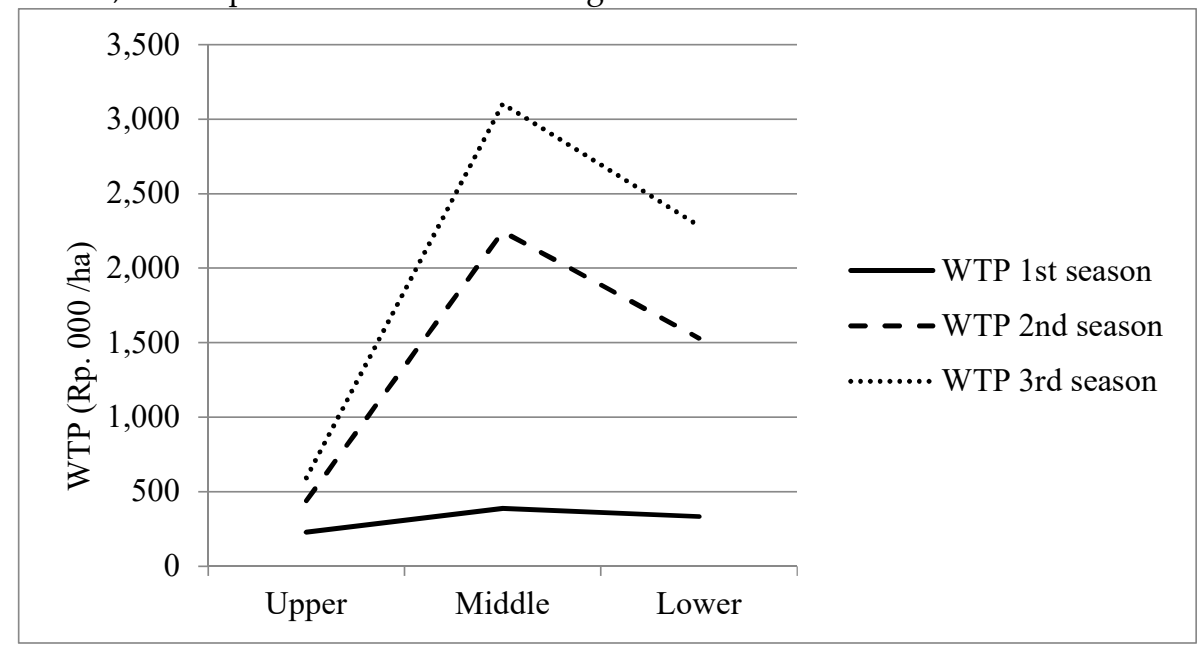

Figure 3. Farmer willingness to pay for irrigation water in each season

\subsection{Determinants of willingness to pay}

The F-Ratio test for the overall fit of model shown in Table 2. It tests the null hypothesis that all coefficients in the model are 0 . Since the significance value of F-ratio is 0.000 , the null hypothesis that all variables coefficients are 0 is rejected. Thus, it can be concluded that the model is better at estimating farmer WTP for irrigation water. The explained variance of dependent variable can be measured with $R^{2}$ value. The $R^{2}$ value of 0.83 indicates that 83 percent of WTP variation can be explained by the model. This percentage is satisfactory since the model doesn't violates the normality, multicollinearity, homoscedasticity, and linearity assumptions.

The t-statistics in Table 2 measure the significance of each independent variable in estimating farmer WTP. If the significance value of each independent variable is small (lower than 0.01 and 0.05 ) then those variables has significance contribution to the model. The t-statistics show that $X 1, X 4, X 5$, and $D$ are significant, significance value is lower than 0.01 for $X 1, X 4$, and D while X5 is lower than 0.05 . The effects of each independent variable are reflected by coefficients value. The negative sign of coefficient indicates that the corresponding variable reduces farmer WTP. Conversely, the positive sign indicates that the corresponding variable increases farmer WTP. The multitude of the effect is reflected by the value of coefficients.

The estimation results show that social variables (X2 and X3) do not significantly affect the value of farmer WTP. Farmer age and education both has $t$-value of -3.012 and -0.027 with significance value of 0,98 and 0,11 respectively. The negative signs of both variables indicate that their increase reduces farmer WTP. These result show that the social characteristics do not affect the value of farmer WTP,

12 The similar result identified by [24] who found that, when faced with water scarcity, farmers employ irrigation system with high efficiency to reduce the use and cost of water and change cropping pattern to cultivate crops with low water requirements. 
the identical result has also been identified by [15] who identified the determinants of WTP for groundwater in Iran. Their study found that social characteristic doesn't significantly affect farmer WTP.

On the other hand, both economic and technical variables affect WTP value significantly. Farm size has negative coefficient while income has positive one, with both have $0.00 p$-value. The result shows that farmer with larger farm tend to be less willing to pay higher irrigation price. Conversely, farmer with higher income tend to be more willing to pay higher irrigation price. Larger farm size will require larger volume of water thus increasing the overall cost of farming, hence farmer with larger farm size tend to be unwilling to pay higher irrigation price. The similar result found in [15] where larger land endowment reduce farmer WTP. Farmer WTP increases with income, since farmers with higher income are able to pay higher irrigation price.

Both technical variables have significant $p$-value, distance to small dam has a negative coefficient while management in dry season has positive coefficient. It means that farmer with plot located far away from water source (small dam) has a higher WTP, since it is increasingly costly to provide water to their farm. It explains why the WTP in middle area is higher than the others, especially in dry season. From eleven water pumps, only two located in the middle area. Consequently, it makes the cost to provide water in middle area is higher. The last variable, management in dry season, has positive coefficient and shows that farmer who used to apply water pump are willing to pay higher irrigation prices.

Table 2. Model estimation results

\begin{tabular}{ccc}
\hline Variable & Coefficients & t-statistics \\
\hline Constants & $1,283,795$ & $1.520(0.13)^{\mathrm{ns}}$ \\
Farm size & $-1,702,240$ & $-3.012(0,00)^{* *}$ \\
Age & $-301,349$ & $-0,027(0,98)^{\mathrm{ns}}$ \\
Education & $-46,701$ & $-1.607(0,11)^{\mathrm{ns}}$ \\
Income & 0.146 & $7.549(0,00)^{* *}$ \\
Distance to small dam & $-750,874$ & $-2.410(0,02)^{*}$ \\
Management in dry season & $2,144,361$ & $9.369(0.00)^{* *}$ \\
Sample size & 100 & \\
R & 0.83 & \\
F-test & 84.18 & \\
Sig. & 0,000 & \\
\hline
\end{tabular}

**significant at $99 \%$ level

*significant at $95 \%$ level

\section{Discussion}

The results of our study confirm the findings of other studies which support the role of water as an economic goods in condition of water scarcity. On dry season when water supply declines, farmer WTP increases significantly. In middle and lower area where water shortage occurs, farmer WTP are high compared to upper area where water is relatively sufficient. We also found that farmer WTP is affected by economic and technical variables. Income, distance from water sources, and application of water pump in dry seasons increase farmer WTP while farm size reduces it.

Irrigation system in the study area can be improved in two ways: by improving irrigation infrastructure and strengthening the role of WUA. Improved irrigation infrastructures will extent the coverage of spring water and thus extending land served by WUA. As shown in Figure 3., mature rice plant receive a lot of water since the irrigation canal cannot be utilized to stop the water flow. On the other hand, rice field in the lower area need those water. Thus, improved irrigation canal will deliver the water to the lower land and makes irrigation more efficient. 


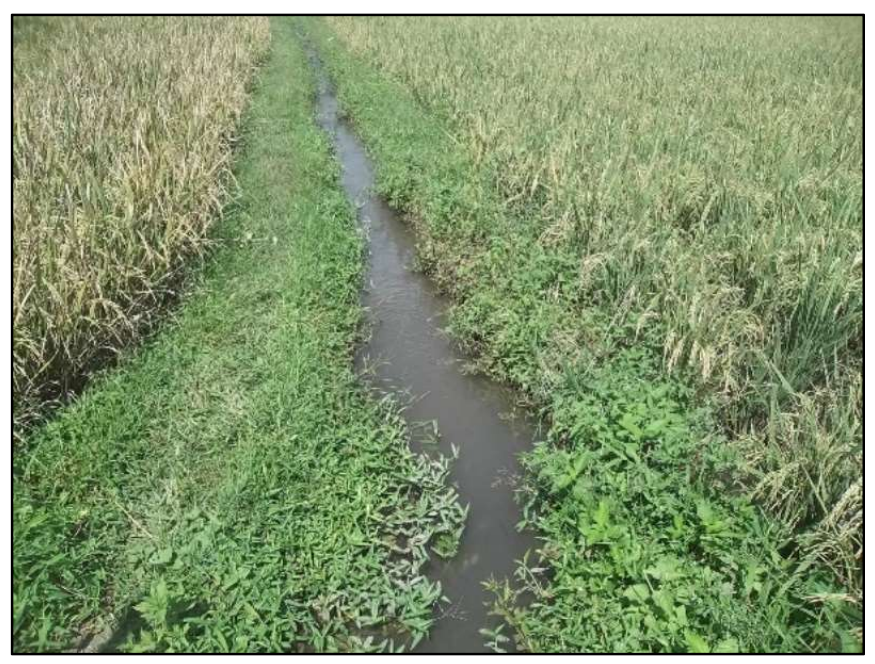

Figure 4. Mature rice plant in the upper area receives too much water due to poor irrigation canal condition

The establishment of irrigation infrastructures can be funded by mobilizing farmer's resources, high farmer WTP indicates that farmers are likely to be willing to participate in those decision. Since, the establishment of irrigation infrastructure will increase irrigation efficiency, increase water availability, and lowering the cost of irrigation. As stated by [16] the availability of canal water strengthens social capital among water user and makes WUA more dynamic.

Moreover, employing development strategy which involves farmers' participation to improve irrigation efficiency proved to be favorable in the long-term. Limiting farmers' participation in the establishment of irrigation infrastructure will reduce their incentives to contribute to infrastructure maintenance, and their collective inaction will lead to low level irrigation performances [17]. Furthermore, when farmers can perceive the benefits they will receive for improved irrigation infrastructures, they are willing to pay more fees for it. As shown in Iran, farmers are willing to pay an additional fee to fund the operations of WUA which reduces their transaction costs associated with irrigation [18]. Apart from the fact that it is difficult to mobilize farmers, we believe that this option is the most appropriate ways in an effort to achieve equity, efficiency, and sustainability of irrigation.

Supplementary Materials: Questionnaire and full dataset used in this study available online at http://dx.doi.org/10.17632/jyvcp5gdds.1

Author Contributions: Conceptualization, Rondhi, M., Peratama, B., Budiman, S., Suwandari, A., and Ridjal, J.; Data Curation, Peratama, B. And Rondhi, M.; Formal Analysis, Rondhi, M.; Writing - original draft, Rondhi, M., Peratama, B., Budiman, S., Suwandari, A., and Ridjal, J.; Writing - review and editing, Rondhi, M.

Funding: This research received no external funding

Conflicts of Interest: The authors declare no conflict of interest

\section{References}

1. Council, W. W. World Water Vision - Making Water Everybody's Business; 2000;

2. Tsur, Y. Economic Aspects of Irrigation Water Pricing. Can. Water Resour. J. 2005, 30, 31-46, doi:10.4296/cwrj300131.

3. Rijsberman, F. R. Water scarcity: Fact or fiction? Agric. Water Manag. 2006, 80, 5-22, doi:10.1016/j.agwat.2005.07.001.

4. Rogers, P.; De Silva, R. D.; Bhatia, R. Water is an economic good: How to use prices to promote equity efficiency and sustainability. Water Policy 2002, 4, 1-17, doi:10.1016/S1366-7017(02)00004-1. 
5. Funnell, D. C. Intervention and indigenous management. Land use policy 1994, 11, 45-54, doi:10.1016/02648377(94)90042-6.

6. Colby, B. G.; Crandall, K.; Bush, D. B. Water right transactions: Market values and price dispersion. Water Resour. Res. 1993, 29, 1565-1572, doi:10.1029/93WR00186.

7. M. Ade Supriyatna, S.; Dhanang Susatyo, S.; Mokh. Subehi, Am.; Hety Sulistiyowati, S.; Aulia Azhar Abdurachman, S. S.; Uliyah, S. S. Statistics of Agricultural Land 2009-2013. 2014, 216.

8. Breidert, C. Estimation of willingness-to-pay: Theory, measurement, application; 2006; ISBN 3835003992.

9. Young, R. A. Determining the Economic Value of Water: Concepts and Methods. Resources For the Future, Washington DC, (2005), ISBN: 1891853988. Ecol. Econ. 2005, 63, 831-832.

10. Tang, Z.; Nan, Z.; Liu, J. The willingness to pay for irrigation water: A case study in Northwest China. Glob. Nest J. 2013, 15, 76-84.

11. Syaukat, Y.; Arifah, F. N.; Minha, F. Economic value and service fee of irrigation water in the districts bogor and kudus, indonesia. J. Int. Soc. Southeast Asian Agric. Sci. 2014, 20, 157-172.

12. Knapp, T.; Kovacs, K.; Huang, Q.; Henry, C.; Nayga, R.; Popp, J.; Dixon, B. Willingness to pay for irrigation water when groundwater is scarce. Agric. Water Manag. 2018, 195, 133-141, doi:10.1016/j.agwat.2017.10.013.

13. Chandrasekaran, K.; Devarajulu, S.; Kuppannan, P. Farmers' Willingness to Pay for Irrigation Water: A Case of Tank Irrigation Systems in South India. Water 2009, 1, 5-18, doi:10.3390/w1010005.

14. Bakopoulou, S.; Polyzos, S.; Kungolos, A. Investigation of farmers' willingness to pay for using recycled water for irrigation in Thessaly region, Greece. Desalination 2010, 250, 329-334, doi:10.1016/j.desal.2009.09.051.

15. Jamali Jaghdani, T.; Brümmer, B. Determinants of willingness to pay for groundwater: insights from informal water markets in Rafsanjan, Iran. Int. J. Water Resour. Dev. 2016, 32, 944-960, doi:10.1080/07900627.2015.1133405.

16. Sheikh, M. J.; Redzuan, M.; Samah, A. A.; Ahmad, N. Identifying sources of social capital among the farmers of the rural Sindh province of Pakistan. Agric. Econ. (Zemědělská Ekon. 2016, 61, 189-195, doi:10.17221/144/2014-AGRICECON.

17. Lam, W. Improving the performance of small-scale irrigation systems: The effects of technological investments and governance structure on irrigation performance in Nepal. World Dev. 1996, 24, 1301-1315, doi:10.1016/0305-750X(96)00043-5.

18. Hassan, M. U.; Qureshi, A. S.; Heydari, N. A Proposed Framework for Irrigation Management Transfer in Iran: Lessons from Asia and Iran; 2007; ISBN 9789290906605.

19. Directorate of Water Resources 14 Criteria for Irrigation Planning; Indonesian Ministry of Public Work: Jakarta, 2010;

20. Kimmage, K.; Adams, W. M. Small-scale farmer-managed irrigation in Northern Nigeria. Geoforum 1990, 21,435-443, doi:10.1016/0016-7185(90)90023-Y.

21. Tarimo, A. K. P. R.; Mdoe, N. S.; Lutatina, J. M. Irrigation water prices for farmer-managed irrigation systems in Tanzania: A case study of Lower Moshi irrigation scheme. Agric. Water Manag. 1998, 38, 33-44, doi:10.1016/S0378-3774(98)00054-7.

22. Hill, J. The Role of Authority in the Collective Management of Hill Irrigation Systems in the Alai (Kyrgyzstan) and Pamir (Tajikistan). Mt. Res. Dev. 2013, 33, 294-304, doi:10.1659/MRD-JOURNAL-D-1200127.1.

23. Hill, J. K. W. Supporting farmer-managed irrigation systems in the Shigar valley, Karakorum: Role of the government and Aga Khan Rural Support Programme. J. Mt. Sci. 2017, 14, 2064-2081, doi:10.1007/s11629017-4496-7.

24. Bozorg-Haddad, O.; Malmier, M.; Mohammad-Azari, S.; Loáiciga, H. A. Estimation of farmers' willingness to pay for water in the agricultural sector. Agric. Water Manag. 2016, 177, 284-290, doi:10.1016/j.agwat.2016.08.011. 